\title{
Canine $\beta$-defensin-1 (CBD1) gene as a possible marker for Leishmania infantum infection in dogs
}

\author{
Lidiane Gomes da Silva', César Raimundo Lima Costa-Júnior', Carlos Alberto Santiago Figueiredo-Júnior', \\ Tereza Cristina Leal-Balbino ${ }^{2}$, Sergio Crovella', Domenico Otranto ${ }^{3}$, Valdir de Queiroz Balbino ${ }^{1+}$ \\ and Filipe Dantas-Torres ${ }^{3,4^{*}+}$ (D)
}

\begin{abstract}
Background: Canine leishmaniasis caused by Leishmania infantum is a parasitic disease of great veterinary significance. Some dogs infected by L. infantum may mount a strong cellular immune response and clear the infection, while others may respond with exaggerated antibody production against the parasite and develop an overt disease, which may be fatal, if left untreated. The initial factors triggering the polarization of the immune response towards a predominantly T-helper 1 or T-helper 2 cytokines, as well as the markers of resistance and susceptibility to L. infantum infection and disease development in dogs, are not fully understood. Herein, we assessed the association between single nucleotide polymorphisms (SNPS) in the canine $\beta$-defensin-1 (CBD1) gene and the infection by L. infantum in two dog populations from Brazil (Sobral in Ceará State and São Raimundo Nonato in Piauí State) and one dog population from Italy.
\end{abstract}

Results: A total of 387 dogs were assessed for $L$. infantum by real time PCR and $34.6 \%$ of them were positive. In CBD1 gene sequences from these positive dogs, nine polymorphic sites were detected, but only SNPs 3, 4, 7 and 8 were associated with L. infantum, in dogs from southern Italy. No association was found with dogs from Brazil.

Conclusion: This study sets the basis for further studies on the usefulness of CBD1 as a marker of $L$. infantum infection susceptibility in dogs.

Keywords: Canine $\beta$-defensin-1 gene, Single nucleotide polymorphisms, Canine leishmaniasis, Dogs

\section{Background}

Canine leishmaniasis (CanL) is a disease caused by sand fly-transmitted protozoa of the genus Leishmania, which affects dogs in all continents, except Oceania [1]. From a global perspective, the most common causative agent of the disease is Leishmania infantum, the agent of zoonotic visceral leishmaniasis in humans. CanL caused by L. infantum is a widespread, life-threatening disease characterized by several, usually non-specific, clinical signs, such as weight loss, enlargement of lymph nodes, spleen and liver, lethargy, cutaneous and ocular lesions [2]. However, most of the L. infantum-infected dogs present neither evident

\footnotetext{
*Correspondence: filipe.dantas@cpqam.fiocruz.br

${ }^{\dagger}$ Equal contributors

${ }^{3}$ Department of Veterinary Medicine, University of Bari, Valenzano, Italy ${ }^{4}$ Department of Immunology, Aggeu Magalhães Institute, Oswaldo Cruz Foundation (Fiocruz), Recife, Brazil

Full list of author information is available at the end of the article
}

clinical signs nor clinico-pathological abnormalities, being generally resistant to the infection $[1,2]$.

The variable clinical presentation of CanL depends on several predisposing factors, including breed, age and genetic background [2]. The development of overt disease is also dependent on the predominant type of immune response mounted by the dog against the parasites. It is known that a dominant T-helper 1 (Th1) cell-mediated immune response may lead to the resolution of infection, whereas an exaggerated T-helper 2 (Th2) cell proliferation can lead to a high antibody production, with the formation of immune complexes, which lead to clinical signs such as vasculitis, arthritis, uveitis, and glomerulonephritis [2, 3]. Undoubtedly, still many gaps remain about the initial factors triggering the polarization of the immune response as well as regarding 
the susceptibility and resistance markers for L. infantum infection in dogs.

Several studies have assessed the usefulness of immunological markers of susceptibility and resistance to L. infantum infection in dogs. For example, interleukin 10 (IL-10), tumour growth factor beta (TGF- $\beta$ ) and interleukin 4 (IL-4) are associated with increased B-cell and plasma-cell activity and hyperglobulinemia, and with disease susceptibility in dogs [3]. On the other hand, increased levels of interferon gamma (IFN- $\gamma$ ), interleukin 2 (IL-2) and tumour necrosis factor alpha (TNF- $\alpha$ ) induce macrophage activation and nitric oxide intracellular killing of parasites, which is associated to resistance in naturally infected dogs [3-6]. Thus, the profile of the host immune response has been used as a marker of susceptibility or resistance to L. infantum infection in dogs.

It has been suggested that host genetics play a role in the susceptibility to CanL. For instance, the solute carrier family 11 member 1 gene (SLC11A1), formerly named resistance-associated macrophage protein 1 (NRAMP1) gene, and certain alleles of the major histocompatibility complex II (MHC II) genes have been associated with susceptibility to CanL $[7,8]$. In a recent study, $\sim 170,000$ single nucleotide polymorphisms (SNPs) were genotyped in dogs and associations between $L$. infantum infection and polymorphisms were found in several genes (e.g. Il7R, Lifr, C6, C7 and Csf1r genes), within a locus involved in lesion development in murine Leishmania major infection [9].

The association between SNPs and L. infantum infection or disease development in dogs is not so clear, since leishmaniasis is a complex disease whose progression is associated with multiple gene loci [10]. SNP analysis of innate immunity genes, such as those coding for antimicrobial peptides (AMPs), could provide interesting insights into the relationship between host's genetics and L. infantum infection in dogs. Herein, we used molecular tools to determine the infection by $L$. infantum in dogs, living in three areas where CanL is endemic, and investigated the possible relationship between polymorphisms in the canine $\beta$ defensin-1 (CBD1) gene and positivity to L. infantum, as previous studies have demonstrated the association of polymorphisms in this gene and diseases in dogs $[11,12]$.

\section{Methods}

\section{Dog populations and samples}

A total of 387 mongrel dogs were included in this study, of which 95 from São Raimundo Nonato $\left(09^{\circ} 00^{\prime} 544^{\prime \prime S}, 42^{\circ}\right.$ $\left.41^{\prime} 56^{\prime \prime W}\right)$, Piauí State, and 190 from Sobral $\left(3^{\circ} 41^{\prime} 15^{\prime \prime}\right.$, $\left.40^{\circ} 21^{\prime} 5^{\prime \prime W}\right)$, Ceará State, north-eastern Brazil. Additionally, 102 dogs from Putignano $\left(40^{\circ} 51^{\prime} \mathrm{N}, 17^{\circ} 7^{\prime} \mathrm{E}\right)$, Apulia region in southern Italy, were also included. Samples from Brazil were primarily collected for this study. The samples from Italy came from a previous study [13]. The selected populations live in known endemic areas of CanL. Venous blood samples $(5 \mathrm{ml})$ from all dogs were collected in tubes containing anticoagulant and stored at $4{ }^{\circ} \mathrm{C}$ until DNA extraction.

\section{Molecular procedures DNA extraction}

DNA extraction from whole blood samples was performed using the salting-out method [14], for the Brazilian samples, and a commercial kit (MagAttract DNA Blood kit, Qiagen, Valencia, California, USA), for the Italian samples. Each extracted DNA sample was quantified by NanoDrop ${ }^{\mathrm{TM}} 2000$ (Thermo Scientific, Wilmington, Delaware, USA) to determine its concentration and purity.

\section{Leishmania DNA detection}

For L. infantum detection, the primers LEISH-1 (5'-AAC TTT TCT GGT CCT CCG GGT AG-3'), LEISH-2 (5'ACC CCC AGT TTC CCG CC-3') and the TaqMan probe FAM-5'-AAA AAT GGG TGC AGA AAT-3'-nonfluorescent quencher-MGB were used as described elsewhere $[13,15]$. These primers target the conserved region of L. infantum of the kinetoplast DNA minicircles conserved region and amplify a fragment of $120 \mathrm{bp}$ [16]. Parasite load was estimated using a standard DNA curve ranging from $1 \mathrm{ng}$ to $0.1 \mathrm{fg}$ of $L$. infantum (MHOM/BR/ 76/M4192) genomic DNA, as described elsewhere [15]. The standard curve and a negative control (no template DNA) were included in each PCR run, which were performed on an QuantStudio 5 Real-Time PCR system (Applied Biosystems, Foster City, California, USA), in a final volume of $15 \mu \mathrm{l}$, containing $2 \mu \mathrm{l}$ of DNA, $2.5 \mu \mathrm{l}$ of nuclease-free water, $1.35 \mu \mathrm{l}$ of each primer at $900 \mathrm{nM}$, $0.3 \mu \mathrm{l}$ of TaqMan ${ }^{\circ}$ probe at $200 \mathrm{nM}$ and $7.5 \mu \mathrm{l}$ of TaqMan ${ }^{\circ}$ Fast Advanced Master Mix (Applied Biosystems, Foster City, California, USA). The cycling conditions were as follows: initial denaturation at $95{ }^{\circ} \mathrm{C}$ for $20 \mathrm{~s}, 40$ cycles at $95^{\circ} \mathrm{C}$ for $1 \mathrm{~s}$ and $60^{\circ} \mathrm{C}$ for $20 \mathrm{~s}$ [15].

Data analysis was performed using QuantStudio ${ }^{\circ}$ Design and Analysis Software v1.3.1 (Applied Biosystems, Foster City, California, USA). PCR-positive dogs were defined as cases and PCR-negative dogs as controls. The parasite load was categorized as described elsewhere [15], considering the estimated number of parasites per $\mathrm{ml}$ of blood as follows: low (0-10 parasites), medium (11-100 parasites), high (101-1000 parasites) or very high (>1000 parasites).

\section{CBD1 gene and SNP analysis}

Primers for CBD1 (DEFEX1FW 5'-ATC CCT GCC CTA TAA ATA CCG-3' and DEFEX1RW 5'-CCA AAC ACA GTC AGG GAT G-3') were designed using the 
Primer3Plus software [17], using Canis lupus familiaris genomic sequences deposited in the GenBank (NC_006598 for the DEFB1 gene). The primers were designed to amplify the region between the promoter and intron 1 of the CBD1 gene with an expected amplicon size of $582 \mathrm{bp}$. The OligoAnalyzer software (http://www.idtdna.com/analyzer/applications/oligoanalyzer) was used to verify the quality of the selected primers based on the observation of the following criteria: melting temperature definition, primer dimer and hairpins formation. PCR standardization was performed in a final volume of $25 \mu \mathrm{l}$ containing: $1.5 \mu \mathrm{l}$ of each primer at a concentration of $10 \mathrm{pmol} / \mu \mathrm{l} ; 7.5 \mu \mathrm{l}$ of nuclease-free water, $12.5 \mu \mathrm{l}$ of GoTaq Master Mix (Promega, Madison, Wisconsin, EUA) and $2 \mu \mathrm{l}$ of DNA. The amplification profile was defined according to the melting temperature of the primer. A gradient was performed to find the perfect annealing temperature and the number of cycles was defined by the size of the fragment specific to the primer.

The amplification conditions for the CBD1 gene were as follows: initial denaturation at $94{ }^{\circ} \mathrm{C}$ for $5 \mathrm{~min}, 35 \mathrm{cy}$ cles of $\left(94{ }^{\circ} \mathrm{C} / 30 \mathrm{~s}, 55{ }^{\circ} \mathrm{C} / 30 \mathrm{~s}\right.$ and $\left.72{ }^{\circ} \mathrm{C} / 30 \mathrm{~s}\right)$, and final extension at $72{ }^{\circ} \mathrm{C}$ for $10 \mathrm{~min}$. The amplified products were analysed in $0.5 \%$ agarose gels, containing $1 \%$ of ethidium bromide and visualized with an ultraviolet transilluminator. All products were sequenced using same primers and the BigDye ${ }^{\circ}$ Terminator v3.1 cycle sequencing kit (Applied Biosystems, Foster City, California, USA), in a Genetic Analyzer 3500 (Applied Biosystems, Foster City, California, USA).

Consensus sequences were generated based on the Phred 40 values using the Staden package [18] and

Table 1 Association between genetic polymorphisms in $\beta$-defensin-1 and with Leishmania infantum in dogs from Sobral, Brazil

\begin{tabular}{|c|c|c|c|c|c|c|c|c|c|c|}
\hline SNP & Variation ID & Position $^{a}$ & Alleles & HWE & $\begin{array}{l}\text { Possible } \\
\text { genotype }\end{array}$ & $\begin{array}{l}\text { Total } \\
\text { frequency } \\
(n=190)\end{array}$ & $\begin{array}{l}\text { Frequency } \\
\text { in cases } \\
(n=70)\end{array}$ & $\begin{array}{l}\text { Frequency } \\
\text { in controls } \\
(n=120)\end{array}$ & $\begin{array}{l}\text { Odds ratio } \\
(95 \% \mathrm{Cl})\end{array}$ & $\begin{array}{l}\text { Logistic } \\
\text { regression } \\
\text { ( } P \text {-value) }\end{array}$ \\
\hline \multirow[t]{3}{*}{ SNP1 } & rs 852527703 & 58881447 & $C / T$ & 0.14 & $T / T$ & 0.23 & 0.19 & 0.25 & $0.51(0.22-1.15)$ & 0.17 \\
\hline & & & & & $C / T$ & 0.44 & 0.40 & 0.47 & $0.59(0.30-1.15)$ & \\
\hline & & & & & $\mathrm{C} / \mathrm{C}$ & 0.33 & 0.41 & 0.28 & 1.00 & \\
\hline \multirow[t]{3}{*}{ SNP2 } & rs852380685 & 58881356 & $C / T$ & 0.14 & $\mathrm{~T} / \mathrm{T}$ & 0.23 & 0.19 & 0.25 & $0.51(0.22-1.15)$ & 0.17 \\
\hline & & & & & $C / T$ & 0.44 & 0.40 & 0.47 & $0.59(0.30-1.15)$ & \\
\hline & & & & & $\mathrm{C} / \mathrm{C}$ & 0.33 & 0.41 & 0.28 & 1.00 & \\
\hline \multirow[t]{3}{*}{ SNP3 } & rs850814192 & 58881297 & $A / G$ & 0.59 & $\mathrm{G} / \mathrm{G}$ & 0.51 & 0.49 & 0.52 & 1.00 & 0.73 \\
\hline & & & & & $A / G$ & 0.42 & 0.43 & 0.42 & $1.11(0.60-2.06)$ & \\
\hline & & & & & $\mathrm{A} / \mathrm{A}$ & 0.07 & 0.09 & 0.06 & $1.59(0.49-5.10)$ & \\
\hline \multirow[t]{3}{*}{ SNP4 } & rs852670798 & 58881294 & $\mathrm{~A} / \mathrm{C}$ & 0.77 & $\mathrm{C} / \mathrm{C}$ & 0.30 & 0.31 & 0.29 & 1.00 & 0.87 \\
\hline & & & & & $\mathrm{A} / \mathrm{C}$ & 0.51 & 0.49 & 0.52 & $0.86(0.44-1.69)$ & \\
\hline & & & & & A/A & 0.19 & 0.20 & 0.18 & $1.01(0.43-2.38)$ & \\
\hline \multirow[t]{3}{*}{ SNP5 } & rs852439766 & 58881277 & $C / T$ & 0.082 & $\mathrm{~T} / \mathrm{T}$ & 0.25 & 0.26 & 0.25 & 1.00 & 0.89 \\
\hline & & & & & $\mathrm{C} / \mathrm{T}$ & 0.56 & 0.54 & 0.57 & $0.92(0.45-1.86)$ & \\
\hline & & & & & $\mathrm{C} / \mathrm{C}$ & 0.18 & 0.20 & 0.18 & $1.11(0.45-2.72)$ & \\
\hline \multirow[t]{3}{*}{ SNP6 } & rs850643698 & 58881159 & $A / G$ & 0.77 & $\mathrm{G} / \mathrm{G}$ & 0.19 & 0.20 & 0.18 & $1.01(0.43-2.38)$ & 0.87 \\
\hline & & & & & $A / G$ & 0.51 & 0.49 & 0.52 & $0.86(0.44-1.69)$ & \\
\hline & & & & & $\mathrm{A} / \mathrm{A}$ & 0.30 & 0.31 & 0.29 & 1.00 & \\
\hline \multirow[t]{3}{*}{ SNP7 } & rs853079810 & 58881122 & $A / G$ & 0.19 & $\mathrm{G} / \mathrm{G}$ & 0.25 & 0.26 & 0.25 & 1.00 & 0.91 \\
\hline & & & & & $A / G$ & 0.55 & 0.53 & 0.56 & $0.92(0.45-1.87)$ & \\
\hline & & & & & $\mathrm{A} / \mathrm{A}$ & 0.20 & 0.21 & 0.19 & $1.09(0.45-2.61)$ & \\
\hline \multirow[t]{3}{*}{ SNP8 } & rs851268228 & 58881093 & $C / T$ & 1 & $T / T$ & 0.08 & 0.10 & 0.07 & $1.57(0.53-4.71)$ & 0.72 \\
\hline & & & & & $C / T$ & 0.41 & 0.40 & 0.41 & $1.03(0.55-1.92)$ & \\
\hline & & & & & $C / C$ & 0.52 & 0.50 & 0.52 & 1.00 & \\
\hline \multirow[t]{3}{*}{ SNP9 } & rs850702571 & 58881081 & $A / G$ & 0.24 & $\mathrm{G} / \mathrm{G}$ & 0.48 & 0.50 & 0.48 & 1.00 & 0.88 \\
\hline & & & & & $A / G$ & 0.39 & 0.37 & 0.41 & $0.86(0.46-1.63)$ & \\
\hline & & & & & $\mathrm{A} / \mathrm{A}$ & 0.12 & 0.13 & 0.12 & $1.05(0.41-2.67)$ & \\
\hline
\end{tabular}


validated by BLAST (http://blast.ncbi.nlm.nih.gov/). The sequences were aligned using the MEGA v.5.3 software [19], which was also used to visualize and quantify the polymorphisms.

\section{Data analysis}

The inter-population differentiation $\left(F_{\mathrm{ST}}\right)$ and the intrapopulation genetic variability $\left(F_{\mathrm{IS}}\right)$ were assessed using Arlequin version 3.11 [20] and GenePop version 4.0 [21]. The correlation between genetic and geographic distances was assessed with Mantel test using Arlequin version 3.11 [20]. Logistic regression was performed to evaluate SNPs and haplotype associations with the infection (case-control) were assessed using SNPStats software (http://bioinfo.icon cologia.net/SNPstats_web), assuming a 5\% significance level
[22]. Statistical power was calculated using G*Power software [23]. This case-control study has $>80 \%$ power to identify a genotype association at the $5 \%$ significance level.

\section{Results}

The real-time PCR positivity values for $L$. infantum were $31.6 \%$ (30/95) in São Raimundo Nonato and $36.8 \%(70 / 190)$ in Sobral. The canine population of Putignano showed a positivity of $33.3 \%$ (34/102). Regarding the parasitic load among the 134 positive dogs, one was considered very highly positive, three were highly positive, nine were medium positive and 121 were low positive (Additional file 1: Table S1).

The PCR product for the CBD1 gene showed a band size of approximately $600 \mathrm{bp}$. The specificity of the PCR

Table 2 Association between genetic polymorphisms in $\beta$-defensin-1 and with Leishmania infantum in dogs from São Raimundo Nonato, Brazil

\begin{tabular}{|c|c|c|c|c|c|c|c|c|c|c|}
\hline SNP & Variation ID & Position $^{a}$ & Alleles & HWE & $\begin{array}{l}\text { Possible } \\
\text { genotype }\end{array}$ & $\begin{array}{l}\text { Total } \\
\text { frequency } \\
(n=95)\end{array}$ & $\begin{array}{l}\text { Frequency } \\
\text { in cases } \\
(n=18)\end{array}$ & $\begin{array}{l}\text { Frequency } \\
\text { in controls } \\
(n=77)\end{array}$ & $\begin{array}{l}\text { Odds ratio } \\
(95 \% \mathrm{Cl})\end{array}$ & $\begin{array}{l}\text { Logistic } \\
\text { regression } \\
(P \text {-value })\end{array}$ \\
\hline \multirow[t]{3}{*}{ SNP1 } & rs852527703 & 58881447 & $\mathrm{C} / \mathrm{T}$ & 0.22 & $\mathrm{~T} / \mathrm{T}$ & 0.32 & 0.43 & 0.26 & 1.00 & 0.10 \\
\hline & & & & & $\mathrm{C} / \mathrm{T}$ & 0.43 & 0.43 & 0.43 & $0.61(0.23-1.61)$ & \\
\hline & & & & & $\mathrm{C} / \mathrm{C}$ & 0.25 & 0.13 & 0.31 & $0.26(0.07-0.95)$ & \\
\hline \multirow[t]{3}{*}{ SNP2 } & rs852380685 & 58881356 & $\mathrm{C} / \mathrm{T}$ & 0.22 & $\mathrm{~T} / \mathrm{T}$ & 0.32 & 0.43 & 0.26 & 1.00 & 0.10 \\
\hline & & & & & $\mathrm{C} / \mathrm{T}$ & 0.43 & 0.43 & 0.43 & $0.61(0.23-1.61)$ & \\
\hline & & & & & $\mathrm{C} / \mathrm{C}$ & 0.25 & 0.13 & 0.31 & $0.26(0.07-0.95)$ & \\
\hline \multirow[t]{3}{*}{ SNP3 } & rs850814192 & 58881297 & $\mathrm{~A} / \mathrm{G}$ & 1 & $\mathrm{G} / \mathrm{G}$ & 0.51 & 0.60 & 0.46 & 1.00 & 0.44 \\
\hline & & & & & $\mathrm{A} / \mathrm{G}$ & 0.42 & 0.33 & 0.46 & $0.56(0.22-1.40)$ & \\
\hline & & & & & $A / A$ & 0.07 & 0.07 & 0.08 & $0.67(0.12-3.80)$ & \\
\hline \multirow[t]{3}{*}{ SNP4 } & rs852670798 & 58881294 & $\mathrm{~A} / \mathrm{C}$ & 1 & $\mathrm{C} / \mathrm{C}$ & 0.48 & 0.63 & 0.42 & 1.00 & 0.10 \\
\hline & & & & & $\mathrm{A} / \mathrm{C}$ & 0.43 & 0.33 & 0.48 & $0.46(0.18-1.15)$ & \\
\hline & & & & & $\mathrm{A} / \mathrm{A}$ & 0.08 & 0.03 & 0.11 & $0.20(0.02-1.79)$ & \\
\hline \multirow[t]{3}{*}{ SNP5 } & rs852439766 & 58881277 & $\mathrm{C} / \mathrm{T}$ & 0.41 & $\mathrm{~T} / \mathrm{T}$ & 0.20 & 0.17 & 0.22 & $0.50(0.14-1.84)$ & 0.47 \\
\hline & & & & & $\mathrm{C} / \mathrm{T}$ & 0.55 & 0.50 & 0.57 & $0.57(0.21-1.56)$ & \\
\hline & & & & & $\mathrm{C} / \mathrm{C}$ & 0.25 & 0.33 & 0.22 & 1.00 & \\
\hline \multirow[t]{3}{*}{ SNP6 } & rs850643698 & 58881159 & $\mathrm{~A} / \mathrm{G}$ & 1 & $\mathrm{G} / \mathrm{G}$ & 0.08 & 0.03 & 0.11 & $0.20(0.02-1.79)$ & 0.10 \\
\hline & & & & & $A / G$ & 0.43 & 0.33 & 0.48 & $0.46(0.18-1.15)$ & \\
\hline & & & & & $\mathrm{A} / \mathrm{A}$ & 0.48 & 0.63 & 0.42 & 1.00 & \\
\hline \multirow[t]{3}{*}{ SNP7 } & rs853079810 & 58881122 & $A / G$ & 0.41 & $\mathrm{G} / \mathrm{G}$ & 0.16 & 0.13 & 0.17 & $0.60(0.15-2.34)$ & 0.67 \\
\hline & & & & & $\mathrm{A} / \mathrm{G}$ & 0.54 & 0.50 & 0.55 & $0.68(0.26-1.78)$ & \\
\hline & & & & & $A / A$ & 0.31 & 0.37 & 0.28 & 1.00 & \\
\hline \multirow[t]{3}{*}{ SNP8 } & rs851268228 & 58881093 & $\mathrm{C} / \mathrm{T}$ & 0.82 & $\mathrm{~T} / \mathrm{T}$ & 0.09 & 0.07 & 0.11 & $0.48(0.09-2.61)$ & 0.53 \\
\hline & & & & & $\mathrm{C} / \mathrm{T}$ & 0.45 & 0.40 & 0.48 & $0.65(0.26-1.62)$ & \\
\hline & & & & & $\mathrm{C} / \mathrm{C}$ & 0.45 & 0.53 & 0.42 & 1.00 & \\
\hline \multirow[t]{3}{*}{ SNP9 } & rs850702571 & 58881081 & $\mathrm{~A} / \mathrm{G}$ & 0.53 & $\mathrm{G} / \mathrm{G}$ & 0.64 & 0.73 & 0.60 & 1.00 & 0.43 \\
\hline & & & & & $\mathrm{A} / \mathrm{G}$ & 0.31 & 0.23 & 0.34 & $0.56(0.21-1.53)$ & \\
\hline & & & & & $\mathrm{A} / \mathrm{A}$ & 0.05 & 0.03 & 0.06 & $0.44(0.05-4.22)$ & \\
\hline
\end{tabular}


was confirmed by BLAST analysis, which presented high levels of similarity (99\%) with a sequence of the CBD1 gene (AC186962.12), which was used as a reference for designing the primers used in this study.

All dog samples were sequenced and DNA fragments of $582 \mathrm{bp}$ were obtained. In the polymorphism analysis, 572 conserved sites and 10 variable sites were detected, and nine of them were parsimony informative. The informative sites were found in the 5 ' untranslated region (position in the chromosome 16: 58881447) and in intron (position in the chromosome 16: 58881356, 58881297, 58881294, 58881277, 58881159, 58881122, 58881093, 58881081) (see Tables 1, 2 and 3). No polymorphic sites were detected in the coding region (exons 1 and 2).
In the population genetics analyses, the $F_{\mathrm{IS}}$ for all SNPs in CBD1 revealed a low inbreeding rate, with values near zero. The $F_{\mathrm{ST}}(0.016)$ indicated low genetic differentiation, demonstrating that the three populations studied are genetically very similar and can be evaluated as a single population. The analysis of allele, genotype and haplotype frequencies showed agreement with the Hardy-Weinberg equilibrium.

When analysing the three populations together, we observed that none of SNPs in CBD1 and haplotypes were associated with the $L$. infantum infection in dogs. With regard to the populations of Sobral and São Raimundo Nonato, data analysis demonstrated that none of the SNPs in CBD1 found was associated with the presence of L. infantum (Tables 1 and 2).

Table 3 Association between genetic polymorphisms in $\beta$-defensin-1 and with Leishmania infantum in dogs from southern Italy

\begin{tabular}{|c|c|c|c|c|c|c|c|c|c|c|}
\hline SNP & Variation ID & Position $^{a}$ & Alleles & HWE & $\begin{array}{l}\text { Possible } \\
\text { genotype }\end{array}$ & $\begin{array}{l}\text { Total } \\
\text { frequency } \\
(n=102)\end{array}$ & $\begin{array}{l}\text { Frequency } \\
\text { in cases } \\
(n=33)\end{array}$ & $\begin{array}{l}\text { Frequency } \\
\text { in controls } \\
(n=69)\end{array}$ & $\begin{array}{l}\text { Odds ratio } \\
(95 \% \mathrm{Cl})\end{array}$ & $\begin{array}{l}\text { Logistic } \\
\text { regression } \\
\text { (P-value) }\end{array}$ \\
\hline \multirow[t]{3}{*}{ SNP1 } & rs852527703 & 58881447 & $C / T$ & 0.16 & $T / T$ & 0.25 & 0.30 & 0.22 & $0.39(0.12-1.23)$ & 0.18 \\
\hline & & & & & $C / T$ & 0.42 & 0.48 & 0.39 & $0.44(0.16-1.23)$ & \\
\hline & & & & & $\mathrm{C} / \mathrm{C}$ & 0.33 & 0.21 & 0.39 & 1.00 & \\
\hline \multirow[t]{3}{*}{ SNP2 } & rs852380685 & 58881356 & $C / T$ & 0.16 & $\mathrm{~T} / \mathrm{T}$ & 0.25 & 0.30 & 0.22 & $0.39(0.12-1.23)$ & 0.18 \\
\hline & & & & & $\mathrm{C} / \mathrm{T}$ & 0.42 & 0.48 & 0.39 & $0.44(0.16-1.23)$ & \\
\hline & & & & & $\mathrm{C} / \mathrm{C}$ & 0.33 & 0.21 & 0.39 & 1.00 & \\
\hline \multirow[t]{3}{*}{ SNP3 } & rs850814192 & 58881297 & $A / G$ & 0.68 & $\mathrm{G} / \mathrm{G}$ & 0.39 & 0.55 & 0.32 & 1.00 & 0.04 \\
\hline & & & & & $A / G$ & 0.45 & 0.39 & 0.48 & $2.08(0.85-5.08)$ & \\
\hline & & & & & $\mathrm{A} / \mathrm{A}$ & 0.16 & 0.06 & 0.20 & $5.73(1.15-28.57)$ & \\
\hline \multirow[t]{3}{*}{ SNP4 } & rs852670798 & 58881294 & $\mathrm{~A} / \mathrm{C}$ & 0.24 & $\mathrm{C} / \mathrm{C}$ & 0.47 & 0.30 & 0.55 & 1.00 & 0.05 \\
\hline & & & & & $\mathrm{A} / \mathrm{C}$ & 0.47 & 0.64 & 0.39 & $0.34(0.14-0.83)$ & \\
\hline & & & & & $\mathrm{A} / \mathrm{A}$ & 0.06 & 0.06 & 0.06 & $0.53(0.08-3.30)$ & \\
\hline \multirow[t]{3}{*}{ SNP5 } & rs852439766 & 58881277 & $C / T$ & 0.83 & $T / T$ & 0.14 & 0.18 & 0.12 & $0.30(0.08-1.15)$ & 0.06 \\
\hline & & & & & $\mathrm{C} / \mathrm{T}$ & 0.49 & 0.61 & 0.43 & $0.34(0.13-0.92)$ & \\
\hline & & & & & $\mathrm{C} / \mathrm{C}$ & 0.37 & 0.21 & 0.45 & 1.00 & \\
\hline \multirow[t]{3}{*}{ SNP6 } & rs850643698 & 58881159 & $A / G$ & 0.33 & $\mathrm{G} / \mathrm{G}$ & 0.06 & 0.06 & 0.06 & $0.58(0.09-3.59)$ & 0.11 \\
\hline & & & & & $\mathrm{A} / \mathrm{G}$ & 0.46 & 0.61 & 0.39 & $0.39(0.16-0.95)$ & \\
\hline & & & & & $A / A$ & 0.48 & 0.33 & 0.55 & 1.00 & \\
\hline \multirow[t]{3}{*}{ SNP7 } & rs853079810 & 58881122 & $A / G$ & 0.67 & $\mathrm{G} / \mathrm{G}$ & 0.14 & 0.18 & 0.12 & $0.30(0.08-1.13)$ & 0.04 \\
\hline & & & & & $A / G$ & 0.44 & 0.58 & 0.38 & $0.31(0.12-0.82)$ & \\
\hline & & & & & $\mathrm{A} / \mathrm{A}$ & 0.42 & 0.24 & 0.51 & 1.00 & \\
\hline \multirow[t]{3}{*}{ SNP8 } & rs851268228 & 58881093 & $C / T$ & 0.68 & $T / T$ & 0.18 & 0.06 & 0.23 & $6.80(1.36-33.88)$ & 0.02 \\
\hline & & & & & $\mathrm{C} / \mathrm{T}$ & 0.46 & 0.42 & 0.48 & $2.00(0.82-4.92)$ & \\
\hline & & & & & $\mathrm{C} / \mathrm{C}$ & 0.36 & 0.52 & 0.29 & 1.00 & \\
\hline \multirow[t]{3}{*}{ SNP9 } & rs850702571 & 58881081 & $A / G$ & 1 & $\mathrm{G} / \mathrm{G}$ & 0.62 & 0.45 & 0.70 & 1.00 & 0.07 \\
\hline & & & & & $\mathrm{A} / \mathrm{G}$ & 0.34 & 0.48 & 0.28 & $0.37(0.15-0.90)$ & \\
\hline & & & & & $\mathrm{A} / \mathrm{A}$ & 0.04 & 0.06 & 0.03 & $0.31(0.04-2.41)$ & \\
\hline
\end{tabular}


The genotypes A/A and T/T within the SNPs 3 and 8, respectively, were associated with the risk of L. infantum infection in dogs from Italy. On the other hand, the genotypes $\mathrm{A} / \mathrm{C}$ and $\mathrm{A} / \mathrm{G}$ within the SNPs 4 and 7, respectively, were associated with protection against $L$. infantum infection (Table 3).

As far as haplotype association is concerned, no haplotypes were found to be associated with L. infantum infection in the studied dog populations.

\section{Discussion}

In this study, we evaluated the possible association between SNPs in the CBD1 gene and L. infantum infection in dogs from north-eastern Brazil and southern Italy. We found an association between some genotypes within SNPs in the CBD1 gene and $L$. infantum infection in dogs from Italy, indicating that these SNPs could be potential genetic markers for the study of $L$. infantum infection susceptibility/resistance in these animals. Yet, no association was found between SNPs in the CBD1 gene and L. infantum infection in the dog populations from Brazil, which may suggest that further studies are needed to confirm the associations found in Italy. These differences could also be related to differences in parasite strains infecting dogs in each studied area. This hypothesis is unlikely because $L$. infantum zymodeme MON-1 is the predominant strain of infecting dogs in the Mediterranean basin and apparently also in South America [24-26]. Another issue that should be considered is population stratification. As all SNPs are potentially under selection pressure, they may not be reliable to assess population stratification. Therefore, the associations found herein could also be due to the underlying structure of the Italian population.

The association between the SNPs in the CBD1 gene and $L$. infantum infection in dogs here described, along with previous studies demonstrating the association between other gene polymorphisms and leishmaniasis in humans [27] and dogs [7-9, 28], indicate that genetic factors may be involved in the susceptibility of $L$. infantum to infection and disease development. Studies conducted by Sanchez-Robert et al. [8, 28] reported an association between a haplotype (TAG-8-141) that includes a SNP in the promoter region and a microsatellite in intron 1, and two SNPs (A4549G in intron 6 and C4859T in exon 8) located in the Slc11a1 gene and susceptibility to leishmaniasis in dogs. In another study, Quilez et al. [9] found associations between polymorphisms in several genes (e.g. Il7R, Lifr, C6, C7 and Csf1r genes) and CanL.

The results of the SNPs association analysis herein presented indicates that $C B D 1$ gene may be involved in the immune response of dogs to L. infantum infection. However, future analysis of the expression levels of the CBD1 gene in dogs infected with $L$. infantum will provide more information about the function of this gene. A previous study evaluated the expression of beta-defensins (i.e. CBD1, CBD103 and CBD108) in the canine respiratory tract and their antimicrobial activity against the intracellular bacterium Bordetella bronchiseptica [11]. All three investigated beta-defensins were detected in respiratory cells and were also readily expressed in skin samples. The study demonstrated that cells infected with canine parainfluenza virus had lower levels of CBD1 and CBD108, as well as that CBD103 presents antimicrobial activity against $B$. bronchiseptica. Another study showed increased expression levels of the $C B D 1$ gene in the skin of dogs with atopic dermatitis compared with healthy individuals [12]. Hypothetically, differences in the expression of the $C B D 1$ gene in the skin of $L$. infantum infected dogs could be associated with the presence/absence/severity of skin lesions commonly seen in dogs with CanL. Again, further research is needed to evaluate the functional effects (if any) of the SNPs found herein and, from a broader perspective, to assess if CBD1 or other beta-defensins display any antimicrobial activity against L. infantum.

\section{Conclusion}

This study demonstrates for the first time a possible association between SNPs in the CBD1 gene and L. infantum infection in dogs. A functional validation of this hypothesis, for example, to assess the level of expression of $\beta$-defensin- 1 in the skin of dogs carrying these SNPs, would be required.

\section{Additional file}

Additional file 1: Table S1. Frequency of Leishmania infantum parasite load categories in dogs from Sobral (SOB) and São Raimundo Nonato (SRN), Brazil, and Italy (ITA). (DOCX $17 \mathrm{~kb}$ )

\section{Acknowledgements \\ This publication has been sponsored by Bayer Animal Health in the framework of the 12th CVBD World Forum Symposium. \\ Funding \\ This study was supported by the Ministry of Health of Brazil and by Bayer Animal Health (Germany).}

Availability of data and materials

The datasets used and/or analysed during the current study available from the corresponding author on reasonable request.

Authors' contributions

LGS, SC, VQB and FDT designed the study; LGS performed the molecular analyses; LGS, CRLCJ, CASFJ and TCLB performed the bioinformatics and population genetics analyses; LGS and FDT wrote the manuscript; DO, VQB and FDT revised the manuscript; VQB and FDT supervised the study and revised the final version of the manuscript. All authors read and approved the final manuscript. 


\section{Competing interests}

The authors declare that they have no competing interests.

\section{Consent for publication}

Not applicable.

\section{Ethics approval}

Sample collection in Brazil was approved (process number 23076.051904/2013-48) by the Animal Ethics Committee (CEUA) of the Biological Sciences Centre, Federal University of Pernambuco. Sample collection in Italy was approved by the Animal Ethics Committee of the University of Bari and by the Italian Ministry of Health (authorization number 72/2009C, no. 69062; 11/28/2008).

\section{Publisher's Note}

Springer Nature remains neutral with regard to jurisdictional claims in published maps and institutional affiliations.

\section{Author details \\ 'Department of Genetics, Federal University of Pernambuco, Recife, Brazil. ${ }^{2}$ Department of Microbiology, Aggeu Magalhães Institute, Oswaldo Cruz Foundation (Fiocruz), Recife, Brazil. ${ }^{3}$ Department of Veterinary Medicine, University of Bari, Valenzano, Italy. ${ }^{4}$ Department of Immunology, Aggeu Magalhães Institute, Oswaldo Cruz Foundation (Fiocruz), Recife, Brazil.}

Received: 9 January 2017 Accepted: 5 April 2017

Published online: 20 April 2017

\section{References}

1. Dantas-Torres F, Solano-Gallego L, Baneth G, Ribeiro VM, de Paiva-Cavalcanti M, Otranto D. Canine leishmaniosis in the Old and New Worlds: unveiled similarities and differences. Trends Parasitol. 2012:28:531-8.

2. Solano-Gallego L, Miró G, Koutinas A, Cardoso L, Pennisi MG, Ferrer L, et al. The LeishVet group. LeishVet guidelines for the practical management of canine leishmaniosis. Parasit Vectors. 2011;4:86-101

3. Reis AB, Giunchetti RC, Carrillo E, Martins-Filho OA, Moreno J. Immunity to Leishmania and the rational search for vaccines against canine leishmaniasis. Trends Parasitol. 2010:26:341-9.

4. Panaro MA, Brandonisio O, Cianciulli A, Cavallo P, Lacasella V, Paradies P, et al. Cytokine expression in dogs with natural Leishmania infantum infection. Parasitology. 2009;136:823-31.

5. Panaro MA, Brandonisio O, de Caprariis D, Cavallo P, Cianciulli A, Mitolo V, et al Canine leishmaniasis in Southern Italy: a role for nitric oxide released from activated macrophages in asymptomatic infection? Parasit Vectors. 2008;9:10

6. Baneth G, Koutinas AF, Solano-Gallego L, Bourdeau P, Ferrer L. Canine leishmaniosis - new concepts and insights on an expanding zoonosis: part one. Trends Parasitol. 2008:24:324-30.

7. Quinnell RJ, Kennedy L, Barnes A, Courtenay O, Dye C, Garcez LM, et al. Susceptibility to visceral leishmaniasis in the domestic dog is associated with MHC class II polymorphism. Immunogenetics. 2003;55:23-8.

8. Sanchez-Robert E, Altet L, Utzet-Sadurni M, Giger U, Sanchez A, Francino O. Slc11a1 (formerly Nramp1) and susceptibility to canine visceral leishmaniasis. Vet Res. 2008;39:36-47.

9. Quilez J, Martínez V, Woolliams JA, Sanchez A, Pong-Wong R, Kennedy LJ, et al. Genetic control of canine leishmaniasis: genome-wide association study and genomic selection analysis. Plos One. 2012:7:1-10.

10. Blackwell JM, Fakiola M, Ibrahim ME, Jamieson SE, Jeronimo SB, Miller EN, et al. Genetics and visceral leishmaniasis: of mice and man. Parasite Immunol. 2009;31:254-66.

11. Erles K, Brownlie J. Expression of beta-defensins in the canine respiratory tract and antimicrobial activity against Bordetella bronchiseptica. Vet Immunol Immunopathol. 2010;135:12-9.

12. Van Damme CM, Willemse T, van Dijk A, Haagsman HP, Veldhuizen EJ. Altered cutaneous expression of beta-defensins in dogs with atopic dermatitis. Mol Immunol. 2009:46:2449-55.

13. Otranto D, de Caprariis D, Lia RP, Tarallo V, Lorusso V, Testini G, et al. Prevention of endemic canine vector-borne diseases using imidacloprid $10 \%$ and permethrin $50 \%$ in young dogs: a longitudinal field study. Vet Parasitol. 2010;20:323-32

14. Miller AS, Dykes DD, Olesky HF. A simple salting-out procedure for extracting DNA from human nucleated cells. Nucleic Acids Res. 1988;16: 1255 .
15. Dantas-Torres F, da Silva Sales KG, Gomes da Silva L, Otranto D, Figueredo LA. Leishmania-FAST15: a rapid, sensitive and low-cost real-time PCR assay for the detection of Leishmania infantum and Leishmania braziliensis kinetoplast DNA in canine blood samples. Mol Cell Probes. 2017;31:65-9.

16. Francino $O$, Altet $L$, Sanchez-Robert E, Rodriguez A, Solano-Gallego L, Alberola J, et al. Advantages of real-time PCR assay for diagnosis and monitoring of canine leishmaniosis. Vet Parasitol. 2006;13:214-21.

17. Untergasser A, Veen HN, Rao X, Bisseling T, Guerts R, Leunissen JAM. Primer3Plus, an enhanced web interface to Primer3. Nucleic Acids Res. 2007:35:71-4.

18. Staden R, Beal KF, Bonfield JK. The Staden package 1998. Methods Mol Biol. 2000;132:115-30.

19. Tamura K, Peterson D, Peterson N, Stecher G, Nei M, Kumar S. MEGA5 Molecular evolutionary genetics analysis using maximum likelihood, evolutionary distance, and maximum parsimony methods. Mol Biol Evol. 2011;28:2731-9.

20. Excoffier L, Lischer HEL. Arlequin suite ver 3.5: A new series of programs to perform population genetics analyses under Linux and Windows. Mol Ecol Resour. 2010;10:564-7.

21. Rousset F. GENEPOP'007: A complete re-implementation of the GENEPOP software for windows and Linux. Mol Ecol Resour. 2008:8:103-6.

22. Solé X, Guino E, Valls J, Iniesta R, Moreno V. SNPStats: A web tool for the analysis of association studies. Bioinformatics. 2006:22:1928-9.

23. Faul F, Erdfelder E, Lang AG, Buchner A. G*Power 3: A flexible statistical power analysis program for the social, behavioral, and biomedical sciences. Behav Res Methods. 2007;39:175-91.

24. Aït-Oudhia K, Harrat Z, Benikhlef R, Dedet JP, Pratlong F. Canine Leishmania infantum enzymatic polymorphism: a review including 1023 strains of the Mediterranean area, with special reference to Algeria. Acta Trop. 2011;118:80-6.

25. Zerpa O, Pratlong F, Ulrich $\mathrm{M}$, Convit J. Isolation of Leishmania infantum, zymodeme MON-1 from canine and human visceral leishmaniasis on Margarita Island. Venezuela Mem Inst Oswaldo Cruz. 2001;96:901-2.

26. Coutinho CE, Santos DO, Baptista C, Figueiredo FB, Madeira MF. Evaluation of Leishmania (Leishmania) chagasi strains isolated from dogs originating from two visceral leishmaniasis-endemic areas in Brazil using multilocus enzyme electrophoresis. Rev Soc Bras Med Trop. 2011:44:572-5.

27. Mehrotra S, Fakiola M, Mishra A, Sudarshan M, Tiwary P, Rani DS, et al. Genetic and functional evaluation of the role of DLL1 in susceptibility to visceral leishmaniasis in India. Infect Genet Evol. 2012;12:1195-201.

28. Sanchez-Robert E, Altet L, Sanchez A, Francino O. Polymorphism of Slc11a1 (Nramp1) gene and canine leishmaniasis in a case-control study. J Hered. 2005:96:755-58

\section{Submit your next manuscript to BioMed Central and we will help you at every step:}

- We accept pre-submission inquiries

- Our selector tool helps you to find the most relevant journal

- We provide round the clock customer support

- Convenient online submission

- Thorough peer review

- Inclusion in PubMed and all major indexing services

- Maximum visibility for your research

Submit your manuscript at www.biomedcentral.com/submit
Biomed Central 